\title{
配水管網における管経路解析および水質 予測手法に関する研究
}

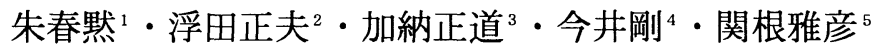 \\ ${ }^{1}$ 正会員 工博 （株）三水コンサルタント （テ171 東京都豊島区目白2丁目1-1） \\ ${ }^{2}$ 正会員 工博 山口大学教授 工学部社会建設工学科（干755 山口県宇部市常盤台 2557 ) \\ ${ }^{3}$ 正会員 工博 九州産業大学教授 工学部土木工学科（广812 福岡市東区松香台 2-3-1） \\ ${ }^{4}$ 正会員 工博 山口大学助手 工学部社会建設工学科（₹755 山口県宇部市常盤台2557） \\ ${ }^{5}$ 正会員 工博 山口大学助教授 工学部社会建設工学科（厂755 山口県宇部市常盤台2557）
}

\begin{abstract}
浄水場から送水される浄水は, 送・配水施設を通過する過程で, THMの增加と残留塩素の減少などの 水質の劣化を受ける. 本研究では, 有限要素法による管網解析手法を発展させ, 管網内の配水池から観測 地点までの水の流下経路, 各経路毎の流量および水の滞留時間の解析手法について検討した. また, $T H M$ と残留塩素を管網内の水質の指標として, 実験により $T H M$ 反応速度式の定式化を行った. これらの結果 より，各節点における合流や分岐の条件を考慮して各節点の残留塩素および THM 濃度を予測する方法を 提案した。これを実際の管網に適応し, 水質調査の結果と照合して解析方法の有効性を検証した.
\end{abstract}

Key Words : pipe net work analysis, pipe path analysis, triharomethane(THM), residual chlorine, water quality prediction

\section{1. 緒言}

平成 4 年 12 月に改正された日本の水道水の水質 基準には, 健康に関連する項目として個々の $T H M$ 4 項目の基準值が新たに示された. 安全で質の高い 水を供給するためには, 原水水質の保全, 浄水場で の適正処理，管路内での水質保持が一体となって機 能すべきである．THM 前駆物質である有機物質が 浄水過程で完全に除去されない場合には管路システ 厶内で残留前駆物質と塩素との反応が継続し, $T H M$ が生成する. 配水過程で浄水場から距離の応じて $T$

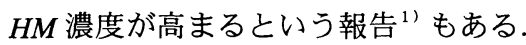

従来, 管路内で生じる水質変化に関する検討は比 較的少なく，管路システムにおける THMの変化に 関しては，必ずしも十分検討が行われてはおらず, 国内では一般に配水管網の水理解析モデルをベース に, 残留塩素濃度に注目して水質解析を行った報告 がなされている.この解析方法としては, 水の流れ を押し出し流れで近似し，各管内での流下時間と節 点における分合流での水質負荷配分を組み合わせる ことで予測する方法が報告されている ${ }^{2)-5) . ~}$

管路内における $T H M$ については, 国内での研究 報告例 ${ }^{4) ， 6)}$ は少なく, 海外では Clark ら ${ }^{7)-9)}$ の表 流水と地下水の混合配水系統での濃度予測 モデル に関する研究が報告されているが，THM の配水系
統内における增加に関しては特に触れられていない. 本研究は, $T H M$, 残留塩素を管網水質指標として, 管網内での水の流下経路, 到達時間解析および管網 内における水質動態の解析方法を提案するものであ る.

\section{2. 研究方法の概要}

本研究では，有限要素法による管網解析手法を発 展させ, 配水管網における水の流下経路解析手法を 検討した. また, 経路毎の流量割合, 経路毎の滞留 時間を計算することによって，管網内のある地点に おける水の平均滞留時間を解析する手法を検討した. 一方, 管網内の水質の指標として, 残留塩素, $T H$ $M$ を取りあげ, 実験により $T H M$ 生成能, 残留塩素 濃度, 反応温度, 反応時間による $T H M$ 反応速度式 の定式化を行った. 管網における残留塩素減少係数 については, 管路の状態や水と管路との接触率など 影響要素を考慮し, 実際管網の実測值より推定する ことにした，管網内の水質については，節点と管路 の接合形態, すなわち, 合流・分流・直列などを考 慮して管網内のすべての節点の水質濃度を解析する 手法を検討した.

さらに，実際の管網の水質解析および水質調査を 


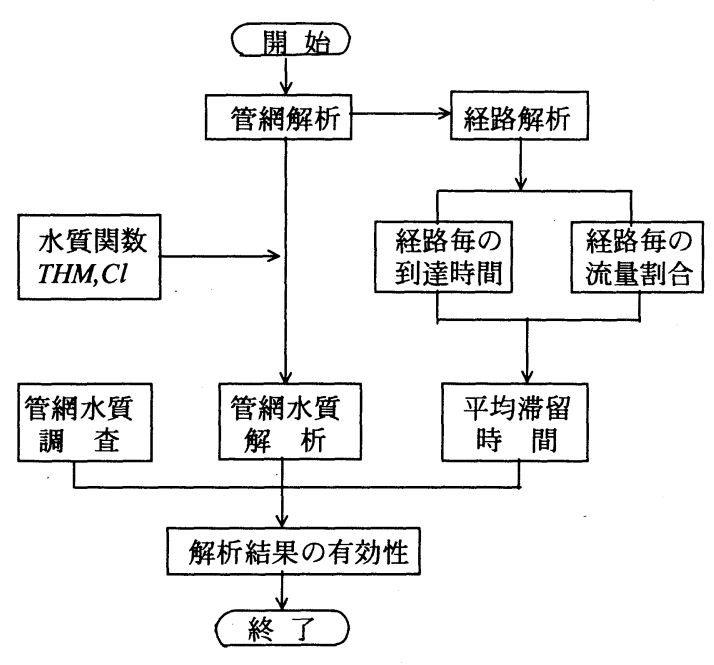

図-1 研究の流れ

行い, 解析結果の有効性の検証を行った. 図-1に本 報における研究の流れを示す.

\section{3. 管網解析および管経路解析手法}

網の目のように発達した管網では，水の流れがた だ一つの経路ではなく無数であり，管網水質解析を 行うためには, 必ずその経路をはっきり割り出すこ とが必要とされる，本報における管網解析では，線 形化を導入した有限要素法 ${ }^{101}{ }^{11}{ }^{11}$ を用い, その結 果にもとづいて, 水の流下経路解析を行った.

\section{（1）線形化による管網計算有限要素法}

配水管網解析を行う上で必要な基礎式と線形化に よる有限要素法の概略は次のようである．管網計算 を行う上で必要な基礎式は下記の 4 個の式である.

流量式 : 一つの管路内の流量 $Q\left[\mathrm{~m}^{3} / \mathrm{s}\right]$ と摩擦損失 水頭 $H[\mathrm{~m}]$ の間には次の関係がある.

$$
H=r Q^{m}
$$

ここに, $m$ [無次元] は指数であり, 流水抵抗 $r$ は抵抗係数 $C$, 管径 $D[\mathrm{~m}]$, 管長 $L[\mathrm{~m}]$ を用いて次 式で示される.

$$
\text { Hazen - Williams式 } \begin{gathered}
r=10.666 C^{-1.85} D^{-4.87} L \\
m=1.85
\end{gathered}
$$

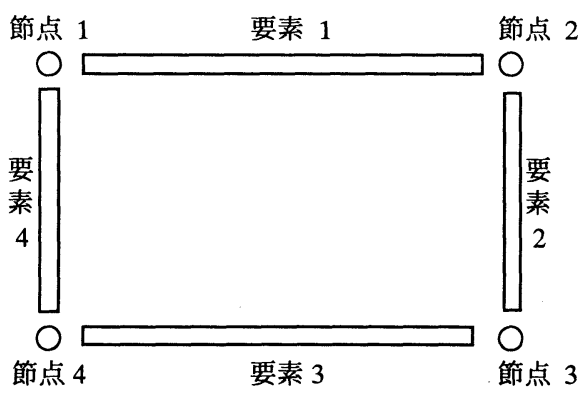

図-2 節点および要素

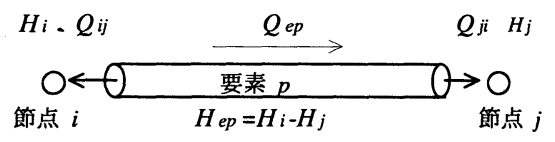

図-3 要素と節点の諸元

節点方程式 : 質量保存則が管路の各節点において成 立する.

$$
\sum_{j=1}^{s} Q_{i j}=Q_{i o u t}
$$

閉管路方程式 : エネルギー平衡が各閉管路において 成立する。

$$
\sum H=0
$$

流出入平衡式 : 管網全体について流出入する水量は 平衡する.

$$
\sum_{i=1}^{p} Q_{i o u t}=0
$$

本報では流量式に線形化をほどこした管網計算の ための有限要素法 ${ }^{101}$ １11) を用いるが，この有限要素 法で特徵的なことは次の 2 点である.

a) 管内摩擦損失水頭と流量の節点値への置き換え

図-2に示す例のように管網を要素と節点に分解し さらに図-3に示すように任意の管内の摩擦損失水 頭 $H_{e p}$ を両端節点の水頭 $H_{i}, H_{j}$ の差として式 (6) で示し, 流量 $Q_{e p}$ を両端の節点値 $Q_{i j}, Q_{j i}$ へ置き 換えて式 (7) を得る.

$$
\begin{aligned}
& H_{e p}=H_{i}-H_{j}, \\
& Q_{e p}=-Q_{i j}=Q_{j i}
\end{aligned}
$$


式 (1), (6), (7)より

$$
H_{e p}=H_{i}-H_{j}=r_{e p} Q_{e p}^{m}
$$

\section{b) 線形化}

式 (8) を有限要素法で解析できる形にする目的で 線形化を行う. 即ち, まず, 非線形項 $Q_{e p}^{m}$ を $Q_{e p}$ と 既知項 $\hat{Q}$ の $(m-1)$ 乗との積と置く $\left(Q_{e p}^{m}=Q_{e p} \cdot \hat{Q}_{e p}^{m-1}\right)$. 次に, 既知項として非線形解析によく用いられる繰 り返し計算における 1,2 回前の值（ $\left.\hat{Q}, \hat{\hat{Q}}_{e p}\right)$ を採用する. 即ち,

$$
H_{i}-H_{j}=r_{e p} Q_{e p}^{m}=r_{e p} Q_{e p} \hat{Q}_{e p}^{(m-1) y} \hat{\hat{Q}}_{e p}^{(m-1)(1-y)}
$$

$¥$ ここに，yは1， 2 回前の值を取り込む割合で あり,この値について数値実験を行った結果 $y=0.8$ を採用 ${ }^{101}$ １11) する. 例えば， 1 回前の值のみを用 いた場合（ $y=1$ に該当）には，本有限要素法による 解が収束しないことがある.また，式 (6) を式 (9) に代入して得られる次式 (10)より $Q_{e p}, Q_{i j}, Q_{j i}$ が計算できる.

$$
-Q_{e p}=Q_{i j}=k_{e p}\left(H_{j}-H_{i}\right), \quad Q_{j i}=k_{e p}\left(H_{i}-H_{j}\right)
$$

ここに, $k_{e p}$ は任意の要素 $p$ の既知項を意味し次 式で示される.

$$
k_{e p}=\left[r_{e p} \hat{Q}_{e p}^{(m-1) y} \hat{\hat{Q}}_{e p}^{(m-1)(1-y)}\right]^{-1}
$$

得られた $Q_{e p}, Q_{i j}, Q_{j i}$ を式(4)へ代入して一つ の要素に関する $Q$ と $H$ の関係式は次のようになる.

$$
\left[\begin{array}{l}
Q_{i j} \\
Q_{j i}
\end{array}\right]=\left[\begin{array}{cc}
-k_{e p} & k_{e p} \\
k_{e p} & -k_{e p}
\end{array}\right]\left[\begin{array}{l}
H_{i} \\
H_{j}
\end{array}\right]
$$

右辺の第一項目はいわゆる要素剛性マトリクスで あり，一つの要素に関する関係式 (12) から全体の $Q$ と $H$ に関する関係式 (13) を求める ${ }^{101,11)}$.

$$
[\bar{K}]\{H\}=\left\{Q_{\text {i out }}\right\}
$$

\section{（2）水の流下経路解析手法}

本研究では, 流入点から観測地点までの経路を求 めるルートプログラムを開発した. 後藤ら ${ }^{3)}$ が提案 した経路解析方法では, 高桑のグラフ理論を用い, 一組の流入点から流出点を含む部分管網を見い出し

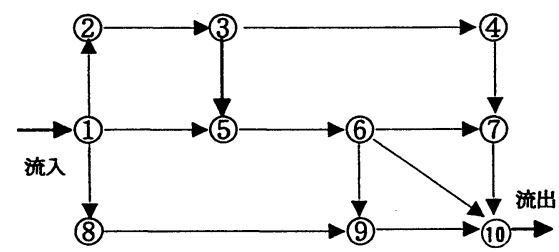

図-4 14 本管路の管網構造

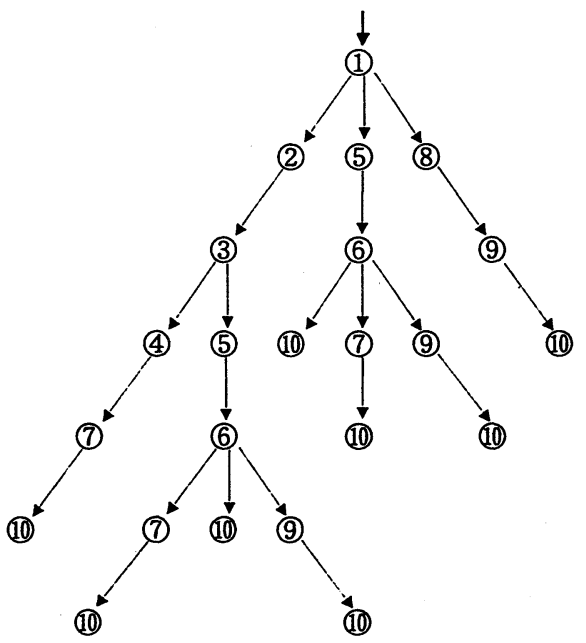

図-5 管網のツリー構造

これの隣接マトリックスを内積するバックトラッキ ング法を使用して管経路を探索している. 一方, 我 々の方法は，管網計算有限要素法の解析結果に基づ いて作成したツリー構造図を用いて, 流出点から逆 に辿って流出点までの経路を求めるものである.

この手法は, 管路変数 $M P$ を 2 次元のマトリクス にすることで, 入出の関係を管路の始点, 終点番号 に表し，図-4に示すような管網を図-5のようにツリ 一状に追跡することによって経路を求める方法であ る. なお，追跡過程に管路が存在するならば管路変 数 $M P=1$, 管路が存在しないと $M P=0$ に定義する ことによって，分岐数の判定を行うことにした．具 体的な解析手順は以下のようである.

a）管網解析結果よりあらかじめ管路の始点, 終点 番号を定め, 経路解析の入力データとする.

b）管網の始点, 目標地点を指定し，始点から目標 地点までを流れる管の要素を選び出し節点ごとの分 岐数を求める.

c）それぞれの節点が次に進む節点を求める.

d）それぞれの節点を分岐数の違いで判断して検定 を行い経路を求める.

e） a)〜d）を与えられた回数だけ繰り返して計算を 
行う.ただし，管の経路が終点に致達しなかった場 合も, 戻って再度計算をしていく.

出力データとして, 経路数, 経路毎の管路番号お よび節点番号で表す.

\section{THM の反応速度式と導出方法}

\section{（1） THM 反応速度式}

有機物質を含む水を塩素処理することにより $T H$ $M$ を生成する反応は有機物質の酸化, ハロゲン化 および加水分解といった素反応が複合したもので, 生成する $T H M$ 量は有機物質濃度 $C$, 残留塩素濃度 $\mathrm{Cl}$, 反応温度 $T$, 反応時間 $t, p H$ などの因子によ って左右され, 次式で表現される.

$$
T H M=f(C, C l, T, t, p H)
$$

$T H M$ 生成に関しては, 実験的に求めた反応速度

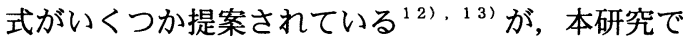
は, 次式によることとした.

$$
\frac{d T H M}{d t}=k[C l][C]^{m} \quad(C: T H M \text { 前駆物 })
$$

$T H M$ 生成能は（THMFP） THM 前駆物質をよく 表す指標であるから $T H M$ 反応速度式は THMFP を 含む式が望ましい，THMFPによる生成式で表現す ると式 (15) となり, $C l$ を既知値とみなし， $t=0$ で $T H M=0$ の条件の下で積分すると式 (16) になる.

$$
\begin{aligned}
& \frac{d T H M}{d t}=K C l(T H M F P-T H M)^{m} \\
& T H M=T H M F P-\left(T H M F P^{(1-m)}+K(m-1) t C l\right)^{\frac{1}{(1-m)}}
\end{aligned}
$$

THMFP は，水の種類と塩素添加量によって異な り, 反応時間を十分長く与えた場合の最大の $T H M$ 生成量である. なお, 式 (15), (16) の反応速度係数 $K$ は $p H$ と反応温度 $T$ の関数となり, $p H$ が一定の 場合式 (17) で表わされる.

$$
K_{T}=K_{20} \mu^{(T-20)}
$$

ここに, $C l$ : 残留塩素濃度 $[\mathrm{mg} / \mathrm{l}]$

THMFP：THM 生成能 $[\mu \mathrm{g} / 1]$

$T$ : 反応温度 $\left[{ }^{\circ} \mathrm{C}\right]$

$t:$ 反応時間 $[\mathrm{hr}]$
表-1 試料水の水質と塩素処理条件

\begin{tabular}{lc|c|c}
\hline \multicolumn{2}{c|}{ 項目 } & 水質值 & 塩素添加濃度 \\
\hline$p H \quad(-)$ & $7.8 \sim 8.5$ & \\
$N H_{4}-N(\mathrm{mg} / \mathrm{l})$ & $0.006 \sim 0.043$ & $1.0 \mathrm{mg} / 1 \sim$ \\
$E_{260} \quad(-)$ & $0.0106 \sim 0.152$ & $4.5 \mathrm{mg} / 1$ \\
$T O C \quad(\mathrm{mg} / \mathrm{l})$ & $1.7 \sim 3.9$ & \\
\hline
\end{tabular}

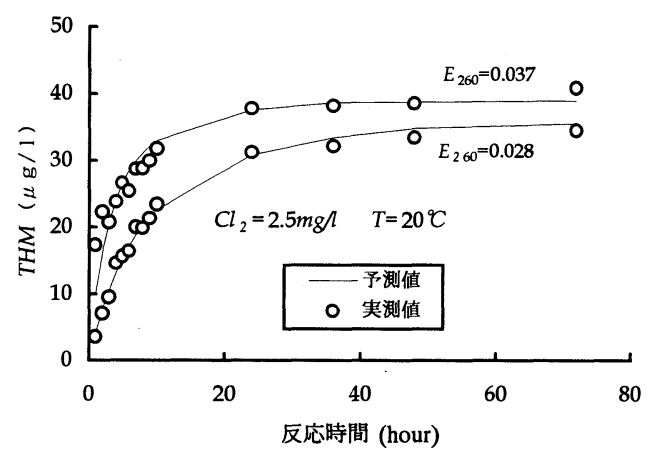

図-7 THMの予測結果

$K r, K 20: T^{\circ} \mathrm{C}, 20^{\circ} \mathrm{C}$ における速度係数 $\left[\mathrm{hr}^{-1}\right]$ $m, \mu$ :係数

なお, 各係数 $K 20, m, \mu$ は実験で求めることが でき, 任意温度における THM 生成速度を解析でき る.

\section{（2） $T H M$ 反応速度式の係数推定実験}

試水は $\mathrm{A}$ 市浄水場で採水した水道原水と沈澱処理 水である. 表-1に試水の主な水質測定值および塩 素添加濃度を示す. 試験方法として, 試水 $1000 \mathrm{ml}$ に $1.0 \mathrm{mg} / \mathrm{ml}$ の次亜塩酸ナトリウム溶液を任意の量 加えて, 塩素添加量を変え, 塩素処理をした後, $50 \mathrm{ml}$ バイアル瓶に注入, 密栓後, $20^{\circ} \mathrm{C}$ の恒温槽に 静置してから, 経時的に THM, 残留塩素濃度を測 定した. THMの定量はへッドスペース・ガスクロ マトグラフ（日立製 263-30 形 $\mathrm{ECD}$ ）により, $\mathrm{CHCl}_{3}$, $\mathrm{CHCI}_{2} \mathrm{Br}, \mathrm{CHCIBr} 2, \mathrm{CHBr}_{3}$ を測定し，その和から $T H M$ 総量を算出した. 残留塩素濃度は $o$-トリジン 比色法により測定した. E 260 については, $1 \mathrm{~cm}$ セル を用いて $260 \mathrm{~nm}$ 波長で測定を行った. その他 TOC, $N_{4}-N$ の測定方法はJIS 法に準拠した.

以上の測定結果を用いて式 (16)により, 係数 $K 20, m$ が推定できる. さらに，反応温度を変える ことにより係数 $\mu$ が決定できる．THMFP は 72 時間後の $T H M$ 生成濃度とした. $20^{\circ} \mathrm{C}$ における $T H M$ の測定結果を用いて最小自乗法により各係数 を推定した結果， $K 20=0.00851 ， \quad m=1.618$ を得た 


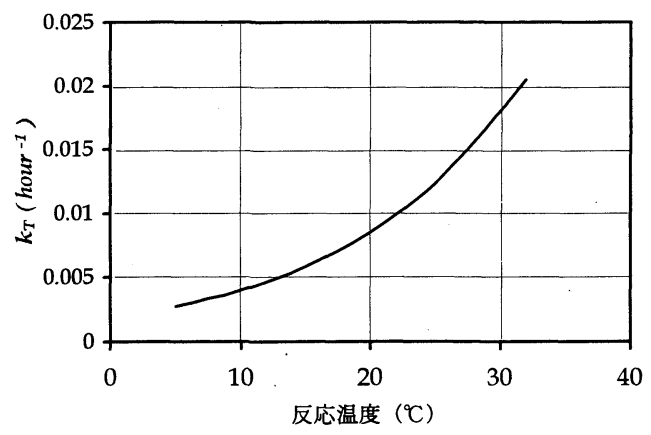

図-8 反応温度と反応速度係数

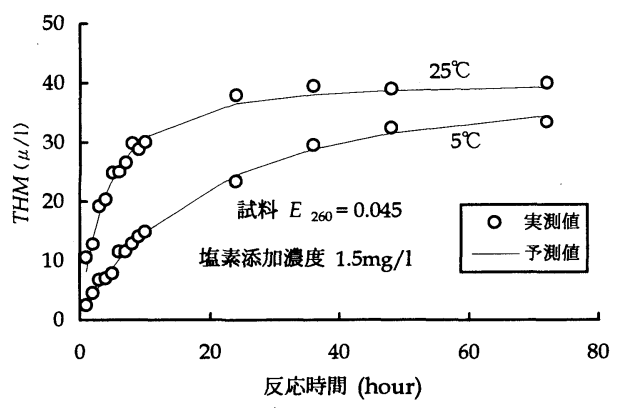

図-9 $5^{\circ} \mathrm{C}, 25^{\circ} \mathrm{C}$ におけるTHM 生成濃度

図-7に $20^{\circ} \mathrm{C}$ における $T H M$ の予測結果の例を示す. また, $5{ }^{\circ} \mathrm{C}, \quad 10^{\circ} \mathrm{C}, \quad 20^{\circ} \mathrm{C}, \quad 30^{\circ} \mathrm{C}$ における $T H M$ の測定結果から補正係数 $\mu=1.078$ が得られた. 図 -8は本実験で求められた反応速度係数と反応温度と の関係を示し，図-9は反応温度が $5{ }^{\circ} \mathrm{C}, 25^{\circ} \mathrm{C}$ の時 の THM の測定結果および予測結果を示すものであ る. (18), (19) 式は, 以上の各係数の推定結果よ り求めた反応速度である.ここで, $C l$ は任意時刻 における残留塩素濃度である.

$$
\begin{aligned}
& \frac{d T H M}{d t}=K_{T} C l(T H M F P-T H M)^{1.618} \\
& K_{T}=0.00851 \times 1.078^{(T-20)}
\end{aligned}
$$

\section{5. 管網における水の滞留時間および水質解析手 法}

\section{（1）平均到達時間の解析手法}

本報では，管経路解析により求められた経路をも とに, 配水池からの流入水量に対する各経路毎の割 合と到達時間を求め, 各節点における水の平均帯留

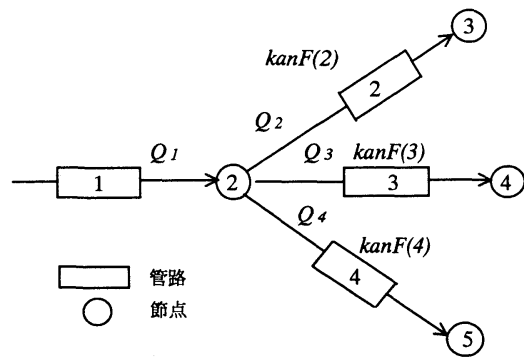

図-10 節点からの分岐流量および割合

時間を計算した．その解析手法および手順は次のと おりである.

分岐数が複数ある節点では, この節点への流入水 量に対し，各流出水量の割合を計算し，その結果を 式 (20)のように管路毎に表す．例えば，図-10に示 すような分岐点において節点(2)から分岐して 3 本の 管路に流れる流量の割合は, 次のとおりである.

管路 $2 ： \operatorname{kanF}(2)=\operatorname{kanH}(2,3)=Q_{2} / Q_{1}$

管路 $3: \operatorname{kan} F(3)=\operatorname{kan} H(2,4)=Q_{3} / Q_{1}$

管路 $4: \operatorname{kan} F(4)=k a n H(2,5)=Q_{4} / Q_{1}$

$$
\operatorname{kanF}(e)=\operatorname{kanH}(i, j)=\frac{Q(i, j)}{Q_{i, \text { 流入 }}}
$$

なお, 管の要素毎の滞留時間は式 (21)より計算 する.

$$
\operatorname{kan} T(e)=\frac{\pi D_{e}^{2} L_{e}}{4 Q_{e}}
$$

ここで, $k a n F$ : 節点から管に流れる流量がその節 点への流入流量に対する割合を管番 号で表したもの

$k a n H ： k a n F$ を節点番号で表したもの

$e \quad$ ：管番号

$i, j \quad$ : 管路の始点, 終点番号

$Q(i, j)$ : 節点から管路への分岐流量

$Q_{i}$ 流入 : 節点 $i$ への流入流量

$k a n T \quad$ : 管路毎の水の滞留時間 $[\mathrm{hr}]$

$D, L, Q$ : 管路の直径, 長さ, 管流量

$$
\left[\mathrm{m}, \mathrm{m}, \mathrm{m}^{3} / \mathrm{s}\right. \text { ] }
$$

各経路を流れる管路を選び出し, 経路ごとの配水 池から観測点までの流量の全体流量（配水池からの 流入水量）に対する割合および到滞留時間を計算す る. ある経路 $n$ の流量の割合は，その経路における 
経路 $n$ の流量割合 $k a n P(n)=k a n F(1) \times k a n F(2) \times \cdots \times k a n F(n q)$

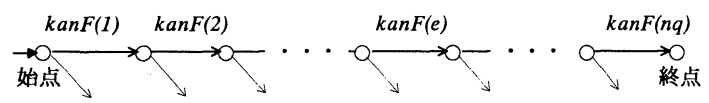

図-11＼cjkstart経路毎の流量割合の概念図

各管路の流量の割合の積であり，観測点までの滞留 時間は, 各管路の滞留時間の和である. 図-11は管路 毎の流量割合と経路毎の流量割合の 概念図であり, 式 (22), 式 (23) は経路毎の流量割合と到達時間の 式である.

$$
\begin{aligned}
& \operatorname{kan} P(n)=\prod_{e=1}^{n q} \operatorname{kan} F(e) \\
& \operatorname{kanTall}(n)=\sum_{e=1}^{n q} \operatorname{kanT}(e)
\end{aligned}
$$

ここで, kanP：配水池からの流入水量に対する 一つの経路の流量の割合

$n$ : 経路番号

$n q:$ 経路の管路数

kanTall : 一つの経路の配水池から観測点ま での滞留時間 $[\mathrm{hr}]$

なお，ある観測点における平均滞留時間は簡略な 方法として, 各経路の流量による重みをつけて式 (24)より計算できる.

$$
\bar{t}_{S}=\frac{\sum_{n=1}^{n l} k a n P(n) \times \operatorname{kanTall}(n)}{\sum_{n=1}^{n l} k a n P(n)}
$$

ここに, $\bar{t}_{S}:$ 節点 $S$ までの平均到達時間 $[h r]$

$$
n: \text { 経路数 }
$$

\section{（2）残留塩素濃度の解析および残留塩素係数の推定 手法}

本研究では, 各管路の水の流下方向, 各管路の節 点における接合方式を考慮して，各節点の水質濃度 を解析する方法を検討した.

配水管網は，管路と管路との間が節点によりつな がれており，管路の中を流下する水塊の管路の上流 端を管路の始点, 下流端を管路の終点とし，また， 水が管路から節点へ流れてくる場合，その管路を上

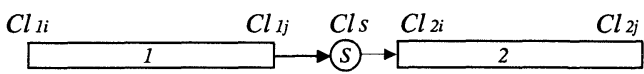

図-12 直列管路

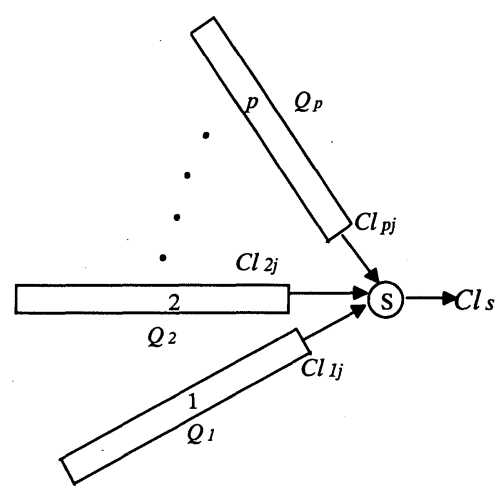

図-13 合流管路

流部管路, 逆に節点から管路へ流れていく場合，下 流部管路とすると，上流部管路の終点は下流部管路 の始点となる.

管網内の残留塩素濃度 $\mathrm{Cl}$ の変化は, 次のような 一次反応にしたがうと考えられている ${ }^{14)}$ 。

$$
\frac{d C l}{d t}=-k_{c} C l
$$

ここで， $k_{c}$ は塩素消費速度係数である.

単一管路中を流下する水塊の管路上流端（始点） の残留塩素濃度を $\mathrm{Cl}$, 下流端（終点）の残留塩素 濃度を $\mathrm{Cl}_{j}$, また 管路内の滞留時間を $\operatorname{kan} T$ とする と, 残留塩素濃度の変化は次のように表現できる.

$$
C l_{j}=C l_{i} e^{-k_{c} \times k a n T}
$$

節点における水質濃度は, 直列・合流・分岐など の管路と節点との接合方式により, 以下のように解 析することができる.

\section{a) 直列管路}

図-12に示すような直列管路の場合，上流部管路 終点の水質濃度は, 下流部管路の始点の水質濃度と なり, 式 (27) で表される.

$$
C l_{s}=C l_{1 j}=C l_{2 i}
$$

\section{b) 合流 - 分岐管路}

図-13に示すように，節点 $S$ に 本の管路が合流 する場合, この節点の残留塩素濃度は物質収支から 
式(28)より計算することができる.

$$
C l_{S}=\frac{\sum_{n=1}^{p}\left[Q_{n} \times C l_{n j}\right]}{\sum_{n=1}^{p} Q_{n}}=\frac{\sum_{n=1}^{p}\left[Q_{n} \times C l_{n i}^{-k_{c n} \times k a n T_{n}}\right]}{\sum_{n=1}^{p} Q_{n}}
$$

ここで, $C l s$ : 節点 $S$ の残留塩素濃度 $[\mathrm{mg} / \mathrm{l}]$

$C l_{n j}$ : 節点 $S$ に合流直前の管路 $n$ の下流

端の残留塩素濃度 $[\mathrm{mg} / \mathrm{l}]$

$C l_{n i}:$ 管路 $n$ の上流端の残留塩素濃度

[mg/l]

$k_{c n}$ : 管路 $n$ の残留塩素減少係数 $\left[\mathrm{hr}^{-1}\right]$

$Q_{n}:$ 管路 $n$ の流量 $\left[\mathrm{m}^{3} / \mathrm{s}\right]$

$p:$ 節点 $S$ への合流する管路数

また，節点に分岐管路がある場合，分岐する管路 始点の残留塩素濃度は, その節点の残留塩素濃度と なる。各管路内の上流端，下流端の残留塩素濃度 の変化は, 式 (26) により解析できる. 管網への流 入点の残留塩素濃度を既知值とすれば, 各節点にお ける管路の接合方式，すなわち，直列・合流・分岐 の状況を判断して, すべて節点の水質解析が可能と なる.

残留塩素減少係数 $k_{c}$ に影響を及ぼす要因につい

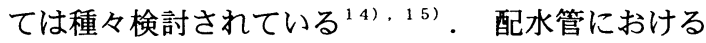
残留塩素係数に影響する要素として, 水温, 水と管 内面との接触率，管材質などが考えられる．ここで は, 後藤に従い, 実際の管網に対して, 式 (29)の ように, 管路の残留塩素濃度の減少係数を管口径 $D$ を説明変数とする指数関数形の回帰式より表すこと にした.

$$
k_{c}=\exp \left(k_{D} \times D+k_{0}\right)
$$

ここで, $k b, k o$ は回帰係数である.

$k_{D}, k_{0}$ の值は，管網への流入点および管網内の 複数点の残留塩素濃度の実測值より推定する方法を 検討した。ある観測点 $S$ の残留塩素濃度観測値を $C l g s$ とし, 計算值を $C l s$ と場合, 適当な $k_{D}, k_{0}$ 值 を与え, 観測值と計算值の誤差 sum が式 (30) を満 足させる $k_{D}, k_{0}$ の値を推定した.

$$
\text { sum }=\sum_{S=1}^{n l}\left(C l_{G S}-C l_{S}\right)^{2} \rightarrow \min
$$

ここに, $n l$ は観測点数である.
係数の推定は, 二つの未知数の場合の最小自乗法を 用い，係数の範囲を指定して行った．以上の方法で 求めた $k_{D}, k_{0}$ の值を用いて, 式 (26) 〜式 (28)より すべて節点における残留塩素濃度が計算できる.

\section{（3） THM 濃度解析}

水中の有機物質との反応による $T H M$ を生成する 過程に関与する残留塩素は少なく, 変化率も小さい, 著者らの $T H M$ 反応速度式の導出の室内実験結果に よると残留塩素減少係数は $0.0325 \mathrm{hr}^{-1}$ であり, 実 際管網においても THM の生成に関与する残留塩素 の量も少なく, 従って残留塩素濃度一定を前提とし て導出した式を用いることが可能である考えられる. 管網内の $T H M$ 濃度は, THM の反応速度が式 (15) にしたがうものと仮定し，1 本の管路における上, 下流端の THM の濃度で表すと式 (31) になる.

$$
\begin{aligned}
T H M_{j}= & T H M F P-\left(\left(T H M F P-T H M_{i}\right)^{(1-m)}\right. \\
& \left.+K_{T}(m-1) k \operatorname{anT} C l_{i}\right)^{\frac{1}{(1-m)}}
\end{aligned}
$$

ここに, $T H M_{j}$ : 管路下流端 $j$ の $T H M$ 濃度 $[\mu \mathrm{g} / \mathrm{l}]$ $T H M i$ : 管路上流端 $i$ の THM 濃度 $[\mu \mathrm{g} / 1]$

各節点における $T H M$ 濃度は, 残留塩素濃度の解 析手法と同様の方法で解析した．例えば合流のある 節点の THM 濃度は, (32) 式で表される.

$$
T H M_{S}=\frac{\sum_{n=1}^{p}\left[Q_{n} \times T H M_{n j}\right]}{\sum_{n=1}^{p} Q_{n}}
$$

管網への流入点の $T H M$ 濃度, 水温, $T H M F P$ を 初期条件とし, 実験的に求められた THM の反応速 度係数 $K_{T}\left(K_{20}, \mu\right)$ および係数 $m$ を用いて, す ベて節点の $T H M$ 濃度が解析できる.

一般に需要水量（各節点からの流出水量 $Q_{i}$ out $)$ は 時間的に変動するが, 本解析では, 有限要素法の 式 (13) において $Q_{i}$ out の時間変動が節点の水頭 $H$ へ, さらに式 (13) を経て管内流量 $Q_{i j}$ へ時間変動の 影響を与え, その結果として, 式 (21)により管路 内の滞留時間 $k a n T$ も時刻により異なる. 言い替え れば, 需要水量に幾種類かの時間変動を与え, これ に伴い $k a n T$ などを変動させることにより, 残留塩 素および THM 濃度解析において疑似的な非定常性 を表すことも可能である. 


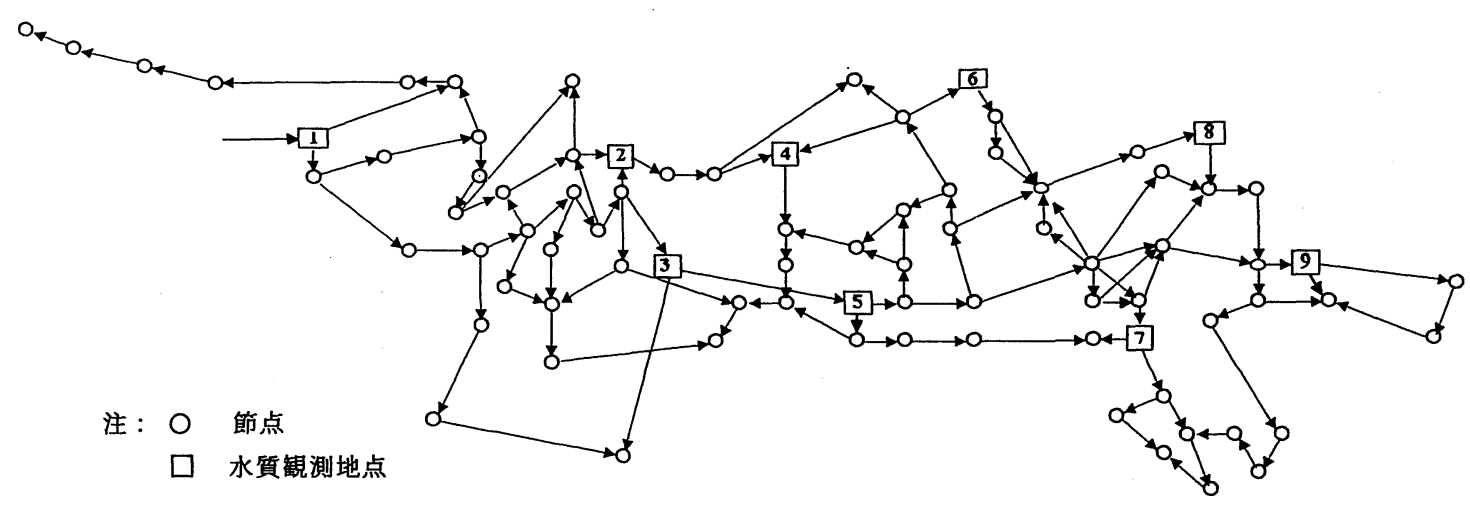

図-14 管網分布およひ水の流下方向

\section{6. 解析結果および考察}

本研究では, 給水人口約 4 万人, 日平均配水量が $16,500 \mathrm{~m}^{3} /$ 日, 管路総延長 $48 \mathrm{~km}$, 配水池から末端 までの距離が約 $10 \mathrm{~km}$ である B 配水管網区（節点 数 : 83 , 管路数：114）を解析対象として, 管網 解析, 管経路解析を行った. また, 管網内の 9 地点 について水質調查を行い, 解析結果と比較すること により，その有効性を検証した．管網解析の入力デ 一タとしては, 水質調查日の配水池の水位の観測值 および検針簿による調查資料を用いた，経路解析は 管網解析の結果にもとづいて行い，管網水質解析は, この配水区の給水源である净水場における $T H M$ 生 成能調查および配水池から配水管網区へ流入する水 道水の $T H M$ 濃度, 残留塩素濃度の調查値（実測値） を用いて行った. なお, 本解析において水需要量は, 日平均値として取り扱ったものであり，水質につい ても日平均值を対象として行った.

\section{（1）管網解析，経路解析および平均到達時間の計算 結果}

解析対象管網区の各節点の水需要量は 7 月 12 日 の平均需要量を入出力条件として管網解析を行い, 配水池から観測点までの流下経路解析は, 管網解 析から得られた出力データを用いて行った. 図-14 に解析対象の配水管網分布および管網解析による水 の流下方向を示す．表-2に経路解析および平均滞留 時間の解析結果を示す。この結果から, 管網の末端 と思われる観測地点 $\mathrm{S} 8$ までの流下経路は 15 であ り，管網における水の経路は部分的に複雑であるこ とがわかる. 図-15には, 同管網区について，同じ 計算条件でエネルギー位法と本法による管路流量の 解析結果の比較を示す．その結果，両法による管路
表-2 管経路解析および平均到達時間の計算結果

\begin{tabular}{c|c|c|c}
\hline 始点番号 * & $\begin{array}{c}\text { 観測点 } \\
\text { 番号 * }\end{array}$ & 経路数 & $\begin{array}{c}\text { 平均到達 } \\
\text { 時間 [hr] }\end{array}$ \\
\hline \multirow{5}{*}{ S1 } & S2 & 4 & 3.98 \\
& S3 & 1 & 3.70 \\
& S4 & 5 & 5.68 \\
& S5 & 1 & 3.97 \\
& S6 & 2 & 7.90 \\
& S7 & 2 & 9.05 \\
& S8 & 15 & 10.82 \\
& S9 & 6 & 11.38 \\
\hline
\end{tabular}

* 図-14の調査地点番号

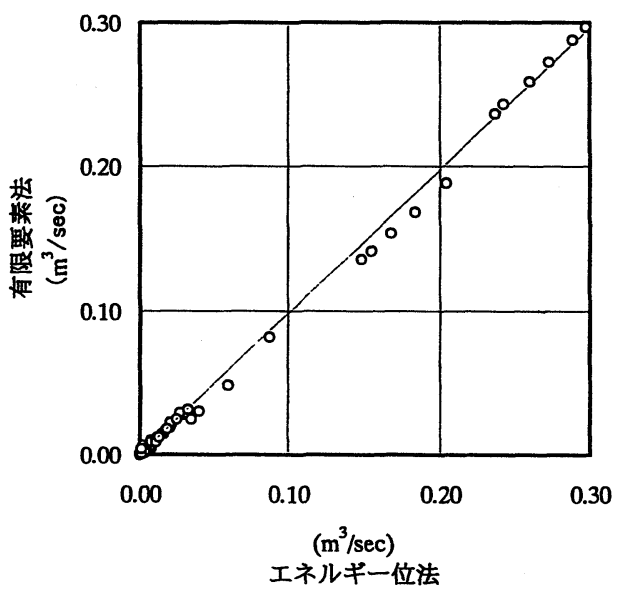

図-15管路流量の計算結果の比較

の流量は概ね一致し，また流向は，管網全体の 114 本管路中， 112 本管路が一致した．このことから, 本法による管網解析は，管路の流れ状態を的確に再 現できると考えられる. 


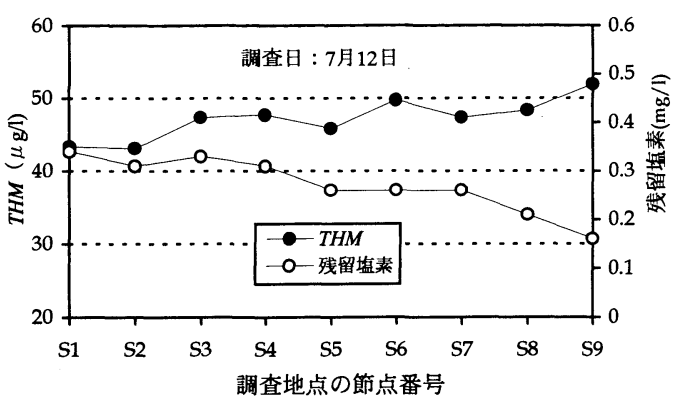

図-16 管網水質調查結果
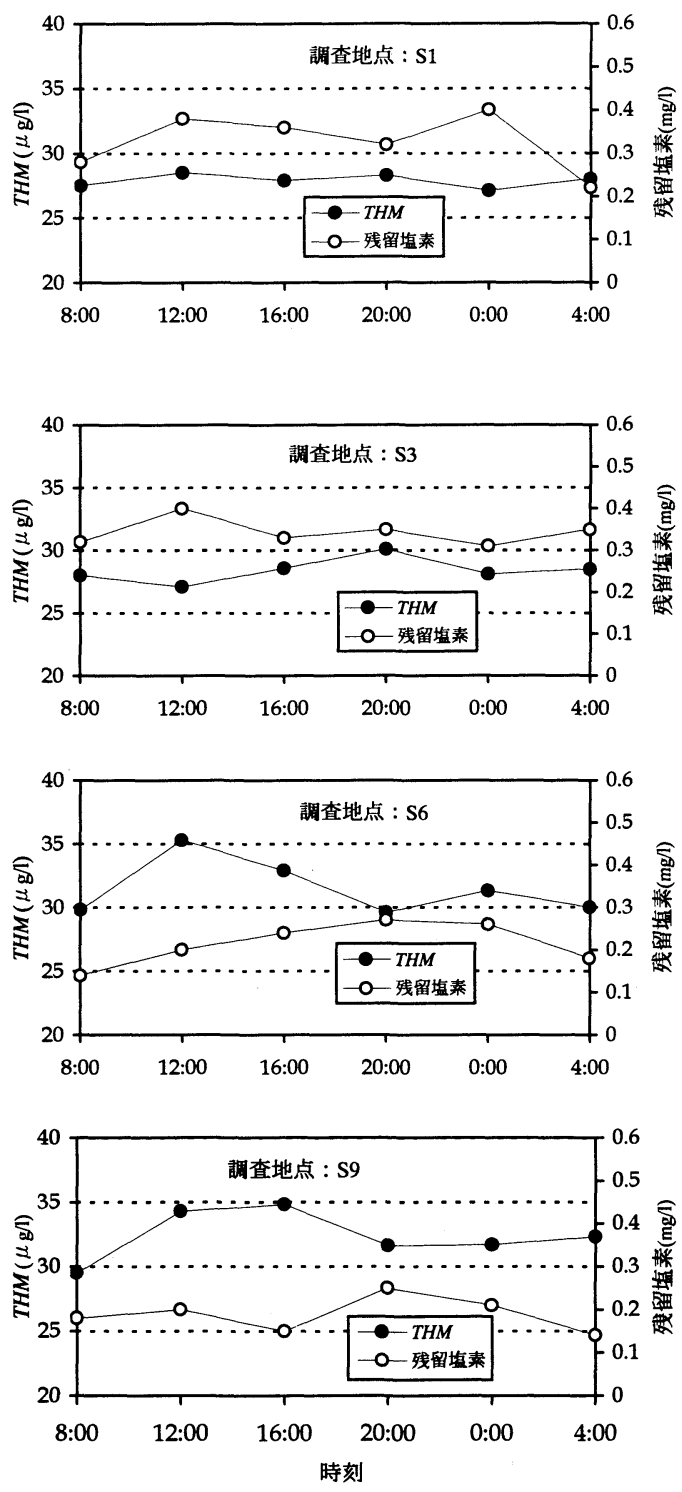

図-17 各調查地点の連続水質調査結果

（調查日：7月24日）

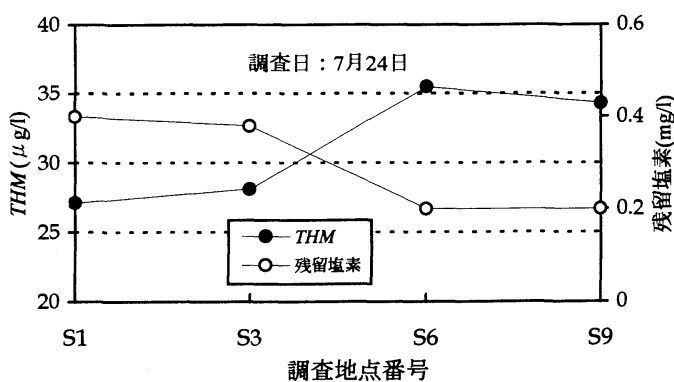

図-18，各地点の水質調査結果(1日平均値)

\section{（2）管網内の水質調査結果}

管網の水質調査は，管網内の 4 9 ケ所を対象 に計 2 回の調査を行った. 第 1 回目の調査は, 平 成 8 年 7 月 12 日に, 9 ケ所を対象に午前 10 時〜 12 時, 午後 2 時〜 4 時に各 1 回行った. 第 2 回目 の調査は, 管網の中の $T H M$ と残留塩素濃度の経 時変化を把握することを目的として, 平成 8 年 7 月 24 日 8 時〜 25 日 4 時に，4地点を対象に 4 時間毎 に各 1 回, 計 6 回の調査を行った. 測定項目は, $p H$, 水温, 残留塩素, $T H M$ である. 水温, $p H$, 残留塩 素は採水現場で測定し ,THM の測定は, $1000 \mathrm{ml}$ 試料水に $4 \mathrm{mg}$ のアスコルビン酸を添加して, 残留 塩素と $T H M$ の反応を止め, 実験室に持ち帰り, 速 やかに分析した. 図-16に, 第 1 回目の調査の残留 塩素濃度と $T H M$ 濃度の平均值を示す。管網の上流 地点から下流地点にいくにつれて, 残留塩素濃度は 徐々に減少し,$T H M$ 濃度は逆に増加することがわ かる. 図-17, 図-18は, 第 2 回目の 24 時間連続調 查の各時刻の 残留塩素と $T H M$ 測定結果を示す. この結果から, 管網の上流地点 $\mathrm{S} 1$ と 3 の 残留塩 素と $T H M$ 濃度は, 経時的に大きな変化はなく, 下 流地点の $T H M$ 濃度は, 昼の 12 時から午後 4 時の間 に増加し, 残留塩素濃度は, 夜 8 時から 12 時の間 に若干高くなる傾向がみられる.

\section{（3） $T H M$ 賑度および残留塩素濃度解析結果}

第 1 回目の管網水質調査の時, $\mathrm{B}$ 管網区の給水源 である $\mathrm{A}$ 市净水場における水道原水（塩素処理の 直前の水）の THMFP を测定した結果, $64 \mu \mathrm{g} / 1$ であった. 管網区への流入地点（図-14の調査地点 番号 S1）の残留塩素濃度の日平均値 $C l 0=0.34 \mathrm{mg} / 1$, $T H M$ 濃度の日平均値 $T H M O=42 \mu \mathrm{g} / 1$ であり, 平均 水温は $23.4{ }^{\circ} \mathrm{C}$ であった。本解析では, これらのデ 一夕を初期値として, 各節点の残留塩素濃度と $T H$ $M$ 濃度の解析を行った. 表一3には, 水質解析の初 期值を示す. なお, 残留塩素減少係数は, 9 ケ所の 
表-3 残留塩素および $T H M$ 濃度解析の初期值 (日平均值)

\begin{tabular}{c|c|c|l|c}
\hline $\begin{array}{c}\text { 項 目 } \\
\text { (単位 ) }\end{array}$ & $\begin{array}{c}T \\
{\left[{ }^{\circ} \mathrm{C}\right]}\end{array}$ & $\begin{array}{c}\text { THMFP } \\
{[\mu \mathrm{g} / 1]}\end{array}$ & $\begin{array}{l}C l o \\
{[\mathrm{mg} / \mathrm{l}]}\end{array}$ & $\begin{array}{c}\text { THMo } \\
{[\mu \mathrm{g} / \mathrm{l}]}\end{array}$ \\
\hline 初期值 & 23.4 & 64 & 0.34 & 42 \\
\hline
\end{tabular}

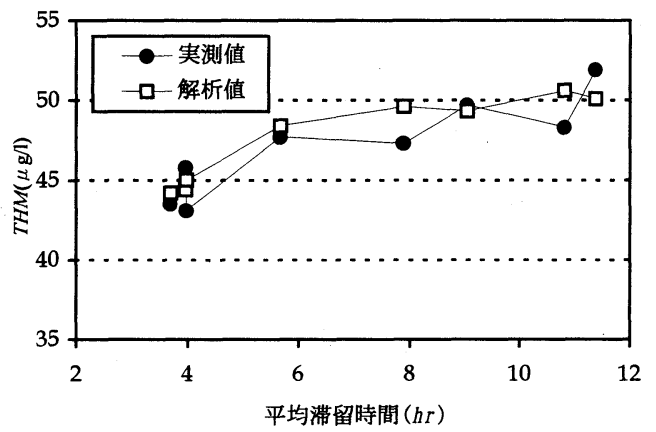

図-19 水の平均滞留時間とTHMの予測値 および実測值（日平均值）

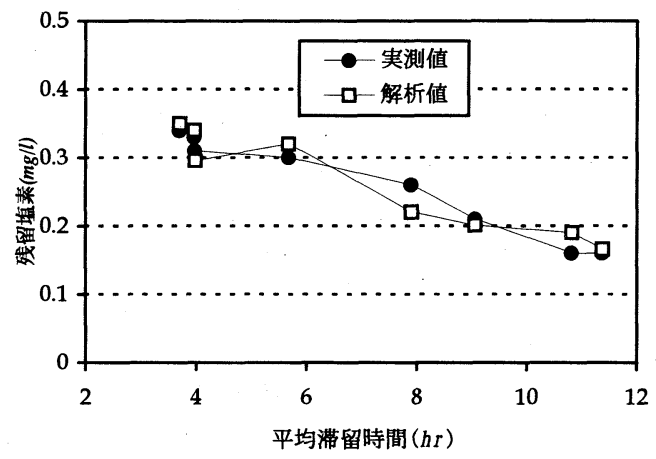

図-20 水の平均滞留時間と残留塩素の予測値 および実測值（日平均值）

残留塩素濃度の実測値を用い, 式 (30) により推定 した. その結果, $k_{D}=-2.744, k_{0}=-1.075$ が得ら れた. 図-19は, 平均滞留時間と $T H M$ 濃度の解析 値, 実測值との比較を示し, 図-20は, 平均滞留時 間と残留塩素濃度の解析值，実測值との関係を示す. その結果, 滞留時間の経過によって THM 濃度は, 徐々に増加し, 残留塩素濃度は, 徐々に減少する ことがわかる. 図-21, 図-22は, THM 濃度, 残留 塩素濃度の解析值と実測値を比較したものである. その結果, $T H M$ 濃度の解析值と実測值との相関 係数は 0.72 , 残留塩素濃度の解析値之実測值との 相関係数は 0.78 であり, 両者とも解析值と実測值 が近いものであることがわかる. 以上の結果から, 本解析手法により，管網内における水質予測が可能 であると考えられる.

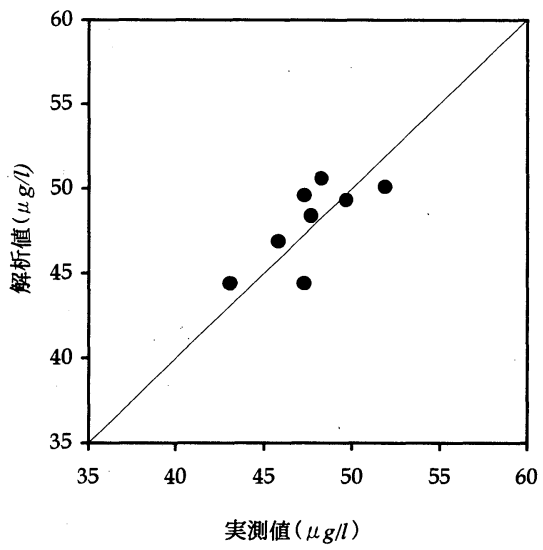

図-21 THM 濃度の解析值と実測值の比較（日平均値）

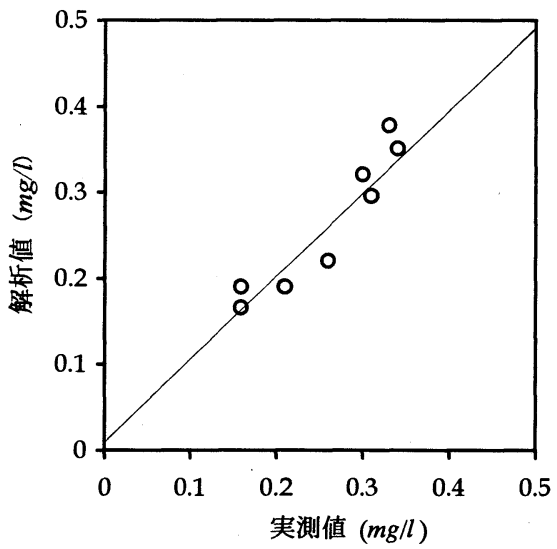

図-22 残留塩素濃度の解析値と実測值の比較（日平均值）

\section{7. 結語}

本報では, 水道水の水質管理に関する研究の一環 として, 配水管網解析, 管網における水の流下経路 解析および水質予測解析法を提案した.

本研究における主な結果を以下にまとめる.

（1）有限要素法による管網解析手法を発展させ，管 網における水の流下経路解析手法を示した.

（2）水の流下経路解析にもとづいて，管網内の水の 滞留時間および分岐, 合流などを考慮した残留塩素, $T H M$ 濃度の予測手法を提案した.

（3）実管網の水質調查結果より，管網の上流部から 下流部にいくにつれて，THM 濃度は徐々に增加し， 残留塩素濃度は徐々に減少することが明らかになっ た． 水温が高い昼ごろの THM 濃度は若干高い傾向 がみられたが，大きな経時変化はみられなかった. 
（4）実管網の管網解析，流下経路解析，水質解析

を行った結果から, 滞留時間の経過とともに, $T H$ $M$ 濃度は徐々に増加し, また, $T H M$, 残留塩素濃 度の解析值と実測值は，概ね一致した結果が得ら れた。

以上のことから，本法による管網内の水質予測が 可能であり，水道水の水質管理に有効であると考え られる。

\section{参考文献}

1）野瀬 善勝: 宇部・小野田両市民の胃癌死亡率之地 質並びに水質との関連性についての疫学的考察， 1988.

2) 小出 崇: 管網における水質分布計算, 水道協会雑誌, No.569, pp.31, 1982.

3）後藤 圭司：配水管網における水質変化（I），水道 協会雑誌, No.569, pp.51, 1982.

4) 住友 垣, 松岡 譲, 延本 浄見: 配水管網における水 質変化の計算, 第 41 回土木学会年次学術講演概要 集II, pp.923, 1986.

5）坂口 博: 配水ブロック内における水質変化, 第 45 回 全国水道研究発表会講演集, pp.332, 1994.

6) 服部 和夫：オゾン・粒状活性炭処理施設の連続流多 重運用モデルによる送水過程でのトリハロメタンシミ ユレーション, 水道協会雑誌, Vol.62, No.8, pp.33, 1993.
7) Clark,R. M..and Coyle, J.A. : Measuring and Modeling Variations in Distribution System Water Quality, Jour, $A W W A$,Vol.82, No.8, pp46-53, 1990.

8) Clark, R.M. and Goodrich, J. A. : Modelling Human Exposure to Contaminantsfoom Drinking Water, $A Q U A$, Vol.41, No.4, pp.224-230, 1992.

9) Clark,R.M. and Smalley,G. : Managing Water Qualty in Distribution Systems : Simulating TTHM and Chlorine Residual Propagation, AQUA, Vol.43, No.4, pp.182-191, 1994.

10) 加納 正道, 黒木 健実 : 土木解析学演習, 理工図書, 1993.

11) Kanoh,M. and Kuroki,T.: Analogy between analysis of flow in pipe networks and slope-deflection in rigid frames, Impact of Computaational Mechanics on Engineering Problems,Sydney,Balkema, 1993.

12）相沢 貴子, 真柄 秦基 : トリハロメタン生成能によ る浄水プロセスの評価 ( I ), 水道協会雑誌, No.557, pp.25, 1981.

13) 住友 恒, 河村 正純 : トリハロメタン生成能の原 水監視, 水道協会雑誌, No.588, pp.26-pp.33, 1983.

14) 中西 弘: 水道施設の塩素処理に関する研究, 水道 協会雑誌, No.386,pp.47-60, 1966.

15）後藤 圭司：配水管網における水質変化（III），水道 協会雑誌, No.571, pp.51-65, 1982.

(1 996.8 .23 受付)

\section{STUDY ON THE ESTIMATION OF WATER QUALITY AND PATH ANALYSIS IN PIPE NETWORK}

\section{Chun mo ZHU, Masao UKITA, Masamiti KANOH, Tsuyoshi IMAI and Masahiko SEKINE}

The methods for simulating the water quality in pipe network were studied by using finite element method. New analytical methods for estimating the flow path from a distribution tank to the observed point and retention time in every pipe path were proposed. Triharomethane (THM) and residual chlorine concentration were selected as indexes of water quality in a pipe network. The equation of THM formation rate was established based on the results of laboratory experiments. Considering the condition of joint or branch, THM and residual chlorine concentration in each pipe node were estimated .Comparing the analytical results with measured values the proposed method was shown to be available. 